\title{
Plant biometrics of malay, rose and water apple
}

\author{
Guilherme Nacata ${ }^{1}$ \& Renata Aparecida de Andrade ${ }^{2}$
}

\begin{abstract}
Due to the lack of studies comparing Syzygium malaccensis(L) Meer \& Perry, Syzygium aqueum Burm.f. and Syzygium jambos (L) Alston Syzygium in relation to the botanical genus Sygygium regarding the physical characteristics, the present research was conducted, aiming at biometrically characterizing each of the three species, as well as comparing them. The fruits were collected from the São Paulo State University (Unesp), School of Agricultural and Veterinarian Sciences, Jaboticabal. Syzygium plants were used for the evaluation of: fruit and seed masses (g); width and length of leaves $(\mathrm{cm})$ and of seeds $(\mathrm{cm})$; percentage of fruit pulp; length of leaf petiole $(\mathrm{cm})$; and leaf area $\left(\mathrm{cm}^{2}\right)$. Fifty fruits, leaves and seeds of each species were used, with 5 replicates of 10 samples each and the data were submitted to descriptive statistical analysis and organized into frequency tables. For comparative purposes among the species, a blocks randomized design was adopted, being analyzed by the Tukey Test at $5 \%$ of probability. The malay and water apple present fruits with high yield of pulp. The fruit of the malay apple are light, with narrow diameter, medium length, broad seeds, narrow and small leaves, with small leaf area. The rose apple fruit present medium mass, width and length, with broad seeds, narrow leaves, medium length and small leaf area. The water apple fruit are light, broad, long, without seeds, with broad leaves, long and having medium leaf area. Comparing the three species of Syzygium studied, it can be concluded that the fruit of malay apple are the largest, but the highest percentage of pulp is found in the fruit of the water apple, due to the absence of seeds.
\end{abstract}

Index terms: Description, morphological characterization,Syzygium, variability.

\section{Biometria vegetal de jambeiros vermelho, rosa e amarelo}

Corresponding author: guilherme_nacata@hotmail.com

Received: April 11, 2017.

Accepted: August 29, 2017

Copyright: All the contents of this journal, except where otherwise noted, is licensed under a Creative Commons Attribution License.

\section{(cc) $\mathrm{EY}$}

Resumo - Devido à carência de estudos que comparem Syzygium malaccensis(L) Meer \& Perry, Syzygium aqueum Burm.f. e Syzygium jambos (L) Alston em relação às características físicas, realizou-se o presente trabalho, visando a caracterizar biometricamente cada uma das três espécies, bem como compará-las. Foram utilizados frutos coletados de plantas de jambeiro da FCAV/UNESP, avaliando-se: massas dos frutos e das sementes $(\mathrm{g})$; largura e comprimento das folhas $(\mathrm{cm})$ e das sementes $(\mathrm{cm})$; porcentagem de polpa dos frutos; comprimento do pecíolo foliar $(\mathrm{cm})$; e área foliar $\left(\mathrm{cm}^{2}\right)$. Foram utilizados 50 frutos, folhas e sementes de cada espécie, tendo-se 5 repetições, com 10 amostras cada. Os dados obtidos foram submetidos à análise estatística descritiva e foram organizados em tabelas de frequência. Para fins comparativos entre as espécies, adotou-se delineamento em blocos casualizados, sendo analisados pelo teste de Tukey, a 5\% de probabilidade. Os jambeiros-vermelho e rosa apresentam frutos com elevado rendimento de polpa. Os frutos do jambeiro-vermelho são leves, de diâmetro estreito, comprimento médio, com sementes largas, folhas estreitas e pequenas, com área foliar pequena. Os frutos de jambeiro-amarelo são de massa, largura e comprimento medianos, com sementes largas, com folhas estreitas, com comprimento médio e área foliar pequena. Os frutos de jambeiro-rosa são leves, largos, compridos, não apresentam sementes, têm folhas largas, compridas e área foliar média. Comparando as três espécies de jambeiro estudadas, conclui-se que os frutos do jambeiro-vermelho são maiores, porém a maior porcentagem de polpa é encontrada nos frutos do jambeiro-rosa, devido à ausência de sementes. Termos para indexação: Caracterização morfológica, descrição, Syzygium, variabilidade.

\footnotetext{
${ }^{1}$ Eng. Agr., Aluno de Doutorado em Agronomia (Fitotecnia), Universidade de São Paulo, Escola Superior de Agricultura "Luís de Queiroz". Piracicaba-SP. E-mail: guilherme_nacata@hotmail.com

${ }^{2}$ Eng. Agr., Prof. Assist. Dr., Universidade Estadual Paulista "Júlio de Mesquita Filho", Faculdade de Ciências Agrárias e Veterinárias, Departamento de Produção Vegetal. Jaboticabal-SP. E-mail: renata.andrade@unesp.br
} 
Among the fruit trees with economic importance, rose apple (Syzygium jambos (L.) Alston), malay apple (Syzygium malaccense (L.) Meer and Perry) and water apple (Syzygium aqueum Burm.f.) can be mentioned, which have the Asian Continent as the Center of Origin and are characterized as fruit trees of tropical climate, used for consumption, urban afforestation, high-quality wood, besides presenting pharmaceutical properties (ORWA et al., 2016).

The knowledge of fruit, leaf and seed characteristics is of great importance for the establishment and multiplication of a species; nevertheless, for the culture of Syzygium there are few studies in relation to plant biometry. Therefore, considering the lack of studies comparing the morphological characteristics of red, pink and yellow Syzygium, the present work aimed at characterizing the biometry of each of the three species, as well as comparing them, providing important information to producers and the scientific community.

The materials used for plant biometry were collected from plants of rose apple (Syzygium jambos (L.) Alston), malay apple (Syzygium malaccense (L.) Meer and Perry) and water apple (Syzygium aqueum Burm.f.), belonging to FCAV, with the evaluation of: fruit and seed mass (grams, using a digital scale with a $0.001 \mathrm{~g}$ precision); leaf width and length and seed width (centimeters, using a graduated ruler, with measurements of width in the central region and length by the distance between the basal and apical regions); leaf petiole length $(\mathrm{cm})$; leaf area $\left(\mathrm{cm}^{2}\right)$, using a leaf area meter LICOR®, model LI 3100); and percentage of fruit pulp (by the difference between fruit and seed masses, pulp mass was obtained and transformed into percentage).

Fifty fruit, leaves and seeds of each species were used, using 5 repetitions with 10 samples each. The data obtained were subjected to the descriptive statistical analysis, using dispersion measures (amplitude and standard deviation). Firstly, the number of classes was determined for the parameters analyzed. Subsequently, data amplitude and frequency interval were calculated, in order to determine the superior and inferior limits.

The data were organized in frequency tables, correlating each class with the frequency detected. The number of classes adopted for all parameters was three, comprising, for mass: light, medium and heavy; for length: short, medium and long; for width: narrow, medium and large; for pulp percentage: low, medium and high; and for leaf area: small, medium and big.

For the comparison among the Syzygium species (red, pink and yellow), a blocks randomized design (BRD) was employed and the data from all variables were analyzed by biometry and compared by the Tukey test at 5\% probability. The software used for the statistical analyses was AgroEstat version 1.1.0.712 (BARBOSA; MALDONADO, 2014).
The fruit of rose apple is of the berry type, hollow and the seed is loose inside it and its pulp has a thickness lower than $5 \mathrm{~mm}$, consisting in the edible part. When unripe, the fruit presents a dark green color and as it increases maturation, it obtains a yellow-greenish coloration (DONADIO, 1998).

By the results obtained fruit rose apple (Syzygium jambos (L.) Alston) are the smallest and lightest, among the three species studied, most of them suiting in the medium class of fruit mass, with fruit presenting median values for percentage of pulp, length and width. The seeds present a small and thin pellicle called tegument and the embryo has green color, with the seeds considered in general heavy and big. The leaves are simple, petiolate and entire, opposite, lanceolate, with medium length, narrow, of small leaf area and with a small petiole (Table 1).

Malay apple (Syzygium malaccense (L.) Meer and Perry), according to Costa et al. (2006), are pyriform, fleshy fruit, berry type, indehiscent, and present whitish mesocarp and endocarp, the last adhered to the seed that presents rigid and green embryos.

It has a thin and smooth epicarp of dark purple color when ripe, which can vary according to the degree of ripeness.

From the results obtained (Table 2), malay apple fruit present the highest mass and are the heaviest among the three species studied, still most of them fitting in the light class of fruit mass defined for this species, with narrow fruit and medium pulp percentage, the seeds present a small and thin pellicle called tegument and the embryo has a green coloration, presenting polyembryony. The leaves are simple, petiolate, entire, opposite, lanceolate, with length, width, petiole length and leaf area in the medium class.

Water apple (Syzygium aqueum Burm.f.) fruit are pyriform, fleshy, indehiscent berry type, with a thin and smooth epicarp of pink color when ripe, varying with the degree of ripeness, with white mesocarp and endocarp (DONADIO, 1998).

Regarding water apple fruit (Table 3), most are observed to fit in the light mass class, being long and large. The leaves are simple, petiolate and entire, opposite, lanceolate, with length, width, petiole length and leaf area in the medium class.

Comparing the three Syzygium species studied, it is observed that there was a significant difference for all variables analyzed, with malay apple presenting the highest values for fruit mass, length and width, seed mass and length, and petiole length, not differing significantly from rose apple in terms of leaf length and width, as well as leaf area.

As rose apple fruit do not present seeds and the percentage of pulp was calculated in this work based on fruit and seed masses, for rose apple the percentage of pulp was equal to the percentage of fruit mass, in other words, $100 \%$ (Table 4). 
Among the three species studied, plant biometry works are only found in literature for malay apple, which enable a more effective comparison of data. For fruit mass, the present work presented means of $58.27 \mathrm{~g}$ for malay apple, which was observed differently by Almeida (2011), who observed a mass of $86.27 \mathrm{~g}$, Falcão et al. (2002), 82.20g, Augusta et al. (2010) 39.16g and Costa et al. (2006) 35.57g.

For pulp percentage, there are reports in literature of very similar rates to that found in the present study (85.23\%) Almeida (2011), 83.13\%, Falcão et al. (2002), $81.70 \%$ and Augusta et al. (2010) $75.69 \%$. For malay apple fruit length and width and seed width, the present work presented, respectively 5.79, 4.75 and $2.64(\mathrm{~cm})$, very close to what is reported in literature for this species, since Costa et al. (2006) found 7.11, 5.15 and $2.33 \mathrm{~cm}$ respectively and Augusta et al. (2010), $5.44 \mathrm{~cm}$ for length and $4.40 \mathrm{~cm}$ for fruit width.

Comparing the data obtained in the present work with reports from other authors, it is observed that there is variability among malay apple fruit in relation to the region in Brazil, as well as in different production periods, an important characteristic to detect in a species, used as a basis for the correct conservation and exploration of the resources with economic value, enabling a lasting increase in the efficient search for fruit and cultural traits (CORREA et al., 2008; OLIVEIRA et al., 2011).

Finally, as a conclusion, we can say that, the malay and water apple present fruits with high yield of pulp. The fruits are light, with narrow diameter, medium length, broad seeds, narrow and small leaves, with small leaf area. The rose apple fruit present medium mass, width and length, with broad seeds, narrow leaves, medium length and small leaf area. The water apple fruits are light, broad, long, without seeds, with broad leaves, long and having medium leaf area.

Comparing the three species of Syzygium studied, it can be concluded that the fruit of malay apple are the largest, but the highest percentage of pulp is found in the fruit of water apple, due to the absence of seeds. 
Table 1. Biometry of rose apple regarding fruit and seed mass (g), pulp percentage (\%), length and width of fruit, leaf and petiole $(\mathrm{cm})$, seed width $(\mathrm{cm})$ and leaf area $\left(\mathrm{cm}^{2}\right)$. UNESP/Jaboticabal, 2016.

\begin{tabular}{|c|c|c|}
\hline & Fruit mass & \\
\hline Class & Frequency interval (g) & Percentage of fruit \\
\hline Light & $7.60-11.41$ & 32 \\
\hline Medium & $11.41-15.21$ & 64 \\
\hline Heavy & $15.21-19.01$ & 4 \\
\hline \multicolumn{3}{|c|}{ Seed mass } \\
\hline Class & Frequency interval (g) & Percentage of seeds \\
\hline Light & $1.71-4.09$ & 66 \\
\hline Medium & $4.09-6.48$ & 8 \\
\hline Heavy & $6.48-8.87$ & 74 \\
\hline \multicolumn{3}{|c|}{ Pulp percentage } \\
\hline Class & Frequency interval (\%) & Percentage of fruit \\
\hline Low & $33.90-88.99$ & 10 \\
\hline Medium & $56.00-77.99$ & 80 \\
\hline High & $78.00-99.97$ & 10 \\
\hline \multicolumn{3}{|c|}{$\begin{array}{ll}\text { Fruit length } \\
\end{array}$} \\
\hline Class & Frequency interval $(\mathrm{cm})$ & Percentage of fruit \\
\hline Short & $2.00-2.77$ & 16 \\
\hline Medium & $2.78-3.44$ & 62 \\
\hline Long & $3.45-4.10$ & 22 \\
\hline \multicolumn{3}{|c|}{ Fruit width } \\
\hline Class & Frequency interval $(\mathrm{cm})$ & Percentage of fruit \\
\hline Narrow & $1.40-2.17$ & 22 \\
\hline Medium & $2.18-2.95$ & 58 \\
\hline Large & $2.96-3.73$ & 20 \\
\hline \multicolumn{3}{|c|}{ Seed width } \\
\hline Class & Frequency interval $(\mathrm{cm})$ & Percentage of seeds \\
\hline Narrow & $0.93-1.39$ & 14 \\
\hline Medium & $1.4-1.84$ & 18 \\
\hline Large & $1.84-2.00$ & 68 \\
\hline \multicolumn{3}{|c|}{ Leaf length } \\
\hline Class & Frequency interval $(\mathrm{cm})$ & Percentage of leaves \\
\hline$\overline{\text { Short }}$ & $11.00-14.66$ & 16 \\
\hline Medium & $14.67-18.32$ & 62 \\
\hline Long & $18.32-22.00$ & 22 \\
\hline \multicolumn{3}{|c|}{ Leaf width } \\
\hline Class & Frequency interval $(\mathrm{cm})$ & Percentage of leaves \\
\hline Narrow & $3.60-4.46$ & 64 \\
\hline Medium & $4.47-5.33$ & 30 \\
\hline Large & $5.34-6.20$ & 6 \\
\hline \multicolumn{3}{|c|}{ Petiole length } \\
\hline Class & Frequency interval $(\mathrm{cm})$ & Percentage of petioles \\
\hline Short & $0.50-0.96$ & 62 \\
\hline Medium & $0.97-1.43$ & 34 \\
\hline Long & $1.44-1.90$ & 4 \\
\hline \multicolumn{3}{|c|}{ Leaf area } \\
\hline Class & Frequency interval $\left(\mathrm{cm}^{2}\right)$ & Percentage of leaves \\
\hline$\overline{\text { Small }}$ & $32.12-51.69$ & 60 \\
\hline Medium & $51.70-71.27$ & 34 \\
\hline Big & $71.28-90.85$ & 6 \\
\hline
\end{tabular}


Table 2. Biometry of malay apple regarding fruit and seed mass (g), pulp percentage (\%), length and width of fruit, leaf and petiole $(\mathrm{cm})$, seed width $(\mathrm{cm})$ and leaf area $\left(\mathrm{cm}^{2}\right)$. UNESP/Jaboticabal, 2016.

\begin{tabular}{|c|c|c|}
\hline & Fruit mass & \\
\hline Class & Frequency interval (g) & Percentage of fruit \\
\hline Light & $35.06-56.20$ & 60 \\
\hline Medium & $56.21-77.35$ & 20 \\
\hline \multirow[t]{2}{*}{ Heavy } & $77.36-98.5$ & 20 \\
\hline & Sees mass & \\
\hline Class & Frequency interval $(\mathrm{g})$ & Percentage of seeds \\
\hline$\overline{\text { Light }}$ & $2.52-7.03$ & 44 \\
\hline Medium & $7.04-11.54$ & 34 \\
\hline \multirow[t]{2}{*}{ Heavy } & $11.55-16.05$ & 78 \\
\hline & $(\%)$ of pulp & \\
\hline Class & Frequency interval $(\%)$ & Percentage of fruit \\
\hline Low & $76.64-82.51$ & 28 \\
\hline Medium & $82.52-88.39$ & 42 \\
\hline \multirow[t]{2}{*}{ High } & $88.40-94.27$ & 30 \\
\hline & Fruit length & \\
\hline Class & Frequency interval $(\mathrm{cm})$ & Percentage of fruit \\
\hline Short & $3.96-4.93$ & 4 \\
\hline Medium & $4.93-5.91$ & 56 \\
\hline \multirow[t]{2}{*}{ Long } & $5.91-6.88$ & 40 \\
\hline & Fruit width & \\
\hline Class & Frequency interval $(\mathrm{cm})$ & Percentage of fruit \\
\hline Narrow & $3.98-4.77$ & 62 \\
\hline Medium & $4.77-5.56$ & 28 \\
\hline \multirow[t]{2}{*}{ Large } & $5.56-6.35$ & 10 \\
\hline & Seed width & \\
\hline Class & Frequency interval $(\mathrm{cm})$ & Percentage of seeds \\
\hline$\overline{\text { Narrow }}$ & $1.69-2.27$ & 20 \\
\hline Medium & $2.28-2.86$ & 46 \\
\hline \multirow[t]{2}{*}{ Large } & $2.86-3.44$ & 66 \\
\hline & Leaf length & \\
\hline Class & Frequency interval $(\mathrm{cm})$ & Percentage of leaves \\
\hline Short & $12.80-16.86$ & 12 \\
\hline Medium & $16.87-20.93$ & 48 \\
\hline \multirow[t]{2}{*}{ Long } & $20.94-25.00$ & 40 \\
\hline & Leaf width & \\
\hline Class & Frequency interval $(\mathrm{cm})$ & Percentage of leaves \\
\hline Narrow & $5.40-7.06$ & 24 \\
\hline Medium & $7.07-8.73$ & 58 \\
\hline \multirow[t]{2}{*}{ Large } & $8.74-10.40$ & 18 \\
\hline & Petiole length & \\
\hline Class & Frequency interval $(\mathrm{cm})$ & Percentage of petioles \\
\hline Short & $0.70-0.96$ & 20 \\
\hline Medium & $0.97-1.23$ & 66 \\
\hline \multirow[t]{2}{*}{ Long } & $1.24-1.50$ & 14 \\
\hline & Leaf area & \\
\hline Class & Frequency interval $\left(\mathrm{cm}^{2}\right)$ & Percentage of leaves \\
\hline Small & $46.97-85.22$ & 26 \\
\hline Medium & $85.23-123.48$ & 54 \\
\hline Big & $123.49-161.74$ & 20 \\
\hline
\end{tabular}


Table 3. Biometry of water apple regarding fruit mass $(\mathrm{g})$, length and width of fruit, leaf and petiole $(\mathrm{cm})$, seed width $(\mathrm{cm})$ and leaf area $\left(\mathrm{cm}^{2}\right)$. UNESP/Jaboticabal, 2016.

\begin{tabular}{|c|c|c|}
\hline & Fruit mass & \\
\hline Class & Frequency interval (g) & Percentage of fruit \\
\hline Light & $8.89-21.86$ & 42 \\
\hline Medium & $21.87-34.83$ & 22 \\
\hline \multirow[t]{2}{*}{ Heavy } & $34.84-47.81$ & 36 \\
\hline & Fruit length & \\
\hline Class & Frequency interval $(\mathrm{cm})$ & Percentage of fruit \\
\hline Short & $2.42-3.28$ & 22 \\
\hline Medium & $3.28-4.13$ & 26 \\
\hline \multirow[t]{2}{*}{ Long } & $4.13-4.99$ & 42 \\
\hline & Fruit width & \\
\hline Class & Frequency interval $(\mathrm{cm})$ & Percentage of fruit \\
\hline Narrow & $2.86-3.70$ & 22 \\
\hline Medium & $3.71-4.54$ & 26 \\
\hline \multirow[t]{2}{*}{ Large } & $4.55-5.38$ & 52 \\
\hline & Leaf length & \\
\hline Class & Frequency interval $(\mathrm{cm})$ & Percentage of leaves \\
\hline Short & $12.00-17.00$ & 16 \\
\hline Medium & $17.01-22.01$ & 50 \\
\hline \multirow[t]{2}{*}{ Long } & $22.02-27.00$ & 66 \\
\hline & Leaf width & \\
\hline Class & Frequency interval $(\mathrm{cm})$ & Percentage of leaves \\
\hline Narrow & $5.50-6.83$ & 18 \\
\hline Medium & $6.84-8.17$ & 34 \\
\hline \multirow[t]{2}{*}{ Large } & $8.18-9.50$ & 48 \\
\hline & Petiole length & \\
\hline Class & Frequency interval $(\mathrm{cm})$ & Percentage of petioles \\
\hline Short & $0.30-0.60$ & 24 \\
\hline Medium & $0.61-0.91$ & 44 \\
\hline \multirow[t]{2}{*}{ Long } & $0.92-1.20$ & 32 \\
\hline & Leaf area & \\
\hline Class & Frequency interval $(\mathrm{cm})$ & Percentage of leaves \\
\hline Small & $45.24-89.25$ & 18 \\
\hline Medium & $89.26-133.27$ & 52 \\
\hline Big & $133.28-177.29$ & 30 \\
\hline
\end{tabular}

Table 4. General means of the species malay apple, rose apple and water apple, for fruit and seed masses (g), pulp percentage $(\%)$, fruit length and width $(\mathrm{mm})$, seed width $(\mathrm{mm})$, leaf length and width $(\mathrm{cm})$ and total area $\left(\mathrm{cm}^{2}\right)$ of leaves and petiole length. UNESP/Jaboticabal, 2016.

\begin{tabular}{|c|c|c|c|c|c|c|c|c|c|c|}
\hline Syzygium & $\begin{array}{l}\text { Fruit mass } \\
\quad(\mathrm{g})\end{array}$ & $\begin{array}{l}\text { Pulp } \\
(\%)\end{array}$ & $\begin{array}{l}\text { Fruit length } \\
\quad(\mathrm{cm})\end{array}$ & $\begin{array}{l}\text { Fruit width } \\
\qquad(\mathrm{cm})\end{array}$ & $\begin{array}{l}\text { Seed mass } \\
\text { (g) }\end{array}$ & $\begin{array}{l}\text { Seed width } \\
\quad(\mathrm{cm})\end{array}$ & $\begin{array}{l}\text { Leaf length } \\
\quad(\mathrm{cm})\end{array}$ & $\begin{array}{l}\text { Leaf width } \\
\text { (cm) }\end{array}$ & $\begin{array}{c}\text { Petiole } \\
\text { length }(\mathrm{cm})\end{array}$ & $\begin{array}{c}\text { Leaf area } \\
\left(\mathrm{cm}^{2}\right)\end{array}$ \\
\hline Malay apple & e58.37a & $85.23 \mathrm{~b}$ & $5.79 \mathrm{a}$ & $4.75 \mathrm{a}$ & $8.55 \mathrm{a}$ & $2.64 \mathrm{a}$ & $19.60 \mathrm{a}$ & $7.62 \mathrm{a}$ & $1.07 \mathrm{a}$ & $104.11 \mathrm{a}$ \\
\hline Rose apple & $12.02 \mathrm{c}$ & $67.62 \mathrm{c}$ & $3.12 \mathrm{c}$ & $2.59 \mathrm{c}$ & $4.00 \mathrm{~b}$ & $1.71 \mathrm{~b}$ & $17.57 \mathrm{~b}$ & $4.38 \mathrm{~b}$ & $0.75 \mathrm{~b}$ & $51.53 \mathrm{~b}$ \\
\hline Water apple & $27.72 \mathrm{~b}$ & $100.00 \mathrm{a}$ & $3.90 \mathrm{~b}$ & $4.31 \mathrm{~b}$ & - & - & $20.69 \mathrm{a}$ & $7.82 \mathrm{a}$ & $0.94 \mathrm{a}$ & $113.85 \mathrm{a}$ \\
\hline $\mathrm{CV} \%$ & 35.76 & 8.73 & 12.57 & 14.07 & 40.40 & 17.29 & 14.52 & 14.97 & 41.73 & 25.80 \\
\hline MSD & 5.54 & 3.48 & 2.54 & 2.59 & 1.00 & 1.49 & 1.32 & 0.46 & 0.18 & 11.00 \\
\hline
\end{tabular}

* Means followed by the same letter do not differ statistically from each other. Tukey test at the level of $5 \%$ probability. 


\section{References}

ALMEIDA V. O. Estudos em mirtáceas em quatro municípios do recôncavo da Bahia. 2011. 92 f. Dissertação (Mestrado em Agronomia - Produção Vegetal) Universidade Federal do Recôncavo da Bahia e Embrapa Mandioca e Fruticultura, Cruz das Almas, Bahia, 2011.

AUGUSTA, I.M.; RESENDE J.M.; BORGES D.V.; MAIA M.C.A.; COUTO A.P.G. Caracterização física e química da casca e polpa de jambo vermelho (Syzygium malaccensis, (L.) Merryl \& Perry). Ciência e Tecnologia de Alimentos, Campinas, v.30, n.4, p.928-932, 2010.

BARBOSA, J.C.; MALDONADO JR, W. AgroEstat sistema para análises estatísticas de ensaios agronômicos. Versão 1.1.0.712. Jaboticabal: FCAV, 2014.

CORRÊA, G.C.; NAVES, R.B.; ROCHA, M.R.; CHAVES, L.J.; BORGES, J.D. Determinações físicas em frutos e sementes de baru (Dipteryx alata Vog.), cajuzinho (Anacardium othonianum Rizz.) e pequi (Caryocar brasiliense Camb.) visando melhoramento génetico. Bioscience Journal, Uberlândia, v.24, n.4, p.42-47, 2008.

COSTA, R.S.; OLIVEIRA, I.V.de M.; MORO, F.V.; MARTINS, A.B.G. Aspectos morfológicos e influência do tamanho da semente na germinação do jambo-vermelho. Revista Brasileira de Fruticultura, Jaboticabal, v.28, n.1, p.117-120, 2006.
DONADIO, C.D.; NACHTGAL, J.C.; SACRAMENTO, C.K. Frutas exóticas. Jaboticabal: FUNEP, 1998. p.120125 .

FALCÃO, M. de A.; PARALUPPI, N.D.; CLEMENT, C.R. Fenologia e produtividade do jambo (Syzygium malaccensis) na Amazônia Central. Acta Amazônica, Manaus, v.32, n.1, p.3-8, 2002.

OLIVEIRA, M.T.R.; BERBERT, P.A.; PEREIRA, R.C.; VIEIRA, H.D.; CARLESSO, V.O. Características biométricas e físico-químicas do fruto, morfologia da semente e da plântula de Averrhoa carambola L. (Oxalidaceae). Revista Brasileira de Sementes, Brasília, DF, v.33, n.2, p.251-260, 2011.

ORWA, C.; MUTUA, A.; KINDT, R.; JAMNADASS, R.; SIMONS, A. Syzygium malaccense (L.) Merr. \& Perry - Myrtaceae. Agroforestree Database: a tree reference and selection guide version 4.0. 2009. Disponível em: $\leq \mathrm{http}: / / \mathrm{www}$.worldagroforestry.org /af/treedb/ $>$. Acesso em: 08 dez. 2016. 